\title{
Age Text
}

National Cancer Institute

\section{Source}

National Cancer Institute. Age Text. NCI Thesaurus. Code C90352.

A textual representation of a chronological age. 